\title{
Gold in Medicine
}

\author{
A REVIEW OF ITS USE IN THE WEST BEFORE 1900
}

\author{
Gregory J. Higby \\ University of Wisconsin School of Pharmacy, Madison, WI., U.S.A.
}

\begin{abstract}
It was natural that the exceptional properties of gold and the mystique surrounding the metal should induce man to seek medicinal applications for it. These attempts met with no apparent success until a few decades ago, when the efficacy of gold compounds in the treatment of theumatoid artbritis was confirmed. Nevertbeless, they form an important, and sometimes colourful, part of the history of pharmacology and medicine.
\end{abstract}

Since earliest times, man has linked the lustre of gold with the warm, life-giving light of the sun. In cultures which deified the sun, gold represented its earthly form. In Egypt, for example, the pharaohs sent out expeditions to bring back gold for their tombs. These rulers saw themselves as descendants of the Sun-God, Re, and required the life-giving properties of gold in the next world (1). For the non-divine residents of Egypt, gold in the form of necklaces and amulets served as a vehicle for magic spells and incantations (2). These amulets, used by magico-religious healers throughout the ancient world from Egypt to India, protected the health of the wearer from evil spirits or spells that might cause illness (3).

The use of gold in medicine for its magico-religious powers continued throughout classical antiquity into our own era (4). In contrast, gold played almost no role in rational therapeutics. Aside from the use of gold wire in jaw fractures, the Hippocratic Corpus (5th century B.C.) is silent (5). Several centuries later, Dioscorides, Celsus, and Galen say nothing about aurum (6). Only the great compiler of the 1st century, Pliny, has a few stories about the medicinal use of gold. According to him, gold heals fistulas and haemorrhoids. He also relays the advice of an encyclopaedist of the 1st century B.C., Marcus Varro, that warts can be cured by rubbing them with gold (7). Pliny, of course, also has magical prescriptions that include gold:

\footnotetext{
'It [gold] is laid upon wounded men and little children to protect them against magic potions. But it has itself a baleful influence when held over them, as it has on the offspring of fowl and cattle. To remedy this, the piece which has been applied should be washed and those whom you wish to cure sprinkled with the washings.' (8)
}

This elaborate process illustrates why early physicians rarely used gold - they had no way to dissolve it or make a soluble product. Even when one heated it with various substances, the gold temained 'true'. The very qualities that made gold special made it difficult to use medicinally.

As the Roman Empire collapsed and Europe slid into the
Middle Ages, gold continued to play a small role in medicine. General knowledge of metallurgy remained high during the period, and artisans continued to produce gold amulets and religious medals to repel evil spirits that might bring on disease (9).

With the rise of Islam in the Middle East, medical scholars built on the works of Galen and Dioscorides. Like their predecessors, Islamic physicians used little gold. Although some authorities, such as Al-Kindi, circa 870, (10), utilized the waste products of gold refining, gold itself was used primarily to coat (gild) pills. This was done both to improve the appearance and taste of medicines and to increase supposedly their therapeutic efficacy (11). More important for the future medicinal use of gold, the Islamic culture preserved the medical and alchemical writings of classical civilization, often adding to, or reorganizing the works. Only with the revival of European alchemy did gold become a prominent medicinal article (12).

\section{The Era of Potable Gold}

Out of late medieval alchemy came the idea of the Elixir of Life: a magical substance that restored youth. As Roger Bacon (1214?-1294) said: 'For that medicine which coutd remove all impurities and corruptions from base metal so that it could become the purest silver or gold is considered by the wise to be able to remove the corruptions of the human body to such a degree that it could prolong life through many ages' (13). Alchemists of the late Middle Ages and early Renaissance searched for this elusive elixir through the use of distillation techniques gleaned from Arabic manuscripts.

By the mid-12th century, European alchemists were able to distil alcohol (aqua ardens or 'burning water') and by the middle of the 13th century, Italian physicians began to prescribe it as a medicine. Searching for ways to purify mercury and sulphur (the Arabic 'constituents' of gold) European alchemists concentrated on the distillation of mineral products (15).

The most notable compiler of this type of alchemical 
knowledge went by the pseudonym of Geber (after the famed Islamic alchemist Jábir ibn Hayán). His 'Summa Perfectionnis Magisterii', written around 1300, 'presented to his world a manual of the general chemical practice of the time, so clear and concise as almost to create an epoch in chemical literature' (16). His works included methods for the production of concentrated mineral acids, such as hydrochloric and nitric acids. These two acids, when mixed in the proper proportions, became aqua regia - the longsought, 'royal' solvent of gold. Through aqua regia, alchemists hoped to learn the secrets locked within the 'purest earthly substance', and perhaps extract the elixir that could turn any metal into gold or could restore lost youth to an aged man.

It was not Geber, however, but a near-contemporary who advocated gold as a medicine: Arnald of Villanova (1235-1311). While little is known of Geber, much is known about the iconoclastic Arnald. A believer in demons and the occult (17), Arnald saw Man as a microcosm of the universe: the planets and their corresponding metals on earth had special relationships with, and powers over, parts of the human body. As Arnald saw it, 'Saturn, by nature cold and dry, governs the stomach of man; Jupiter, warm and moist, the liver; Mars, hot and dry, the kidneys; the Sun, hot and dry, the heart; Venus, warm and moist, the testicles; Mercury, cold and moist, the bladder; the moon, cold and moist, the brain' (18).

These ideas were not new, Hippocrates had attributed to the stars definite power over the body. Arnald, however, extended this model and put special emphasis on the role of gold. He wrote of this metal:

'It owes its perfection to the unique and admirable balance of elementary constituents and virtues therein. In addition, it harbours specific virtues which are due to celestial influence. In its stability and permanence, gold is itself like a star of heaven. Though an object composed of elements, it is unalterable, insoluble, incorruptible - a miracle of nature. It helps vision, and above all, cleanses and clears the substance of the heart and the fountain of life'. (19)

Alchemical philosophers for the next 400 years harkened back to this interrelationship among the sun, gold and the human heart.

For the above reasons, Arnald advocated the medicinal use of gold in a form that could be internally consumed, that is potable gold or aurum potabile. Clearly, Arnald was ignorant of aqua regia. Thus, it is not suprising that his favourite recipe for potable gold called for the preparer to quench a heated gold plate in a container of wine, four or five times. Perhaps a tasty drink, but one that contained no gold (20).

Nevertheless, Arnald, the Spaniard Raymundus Lullus

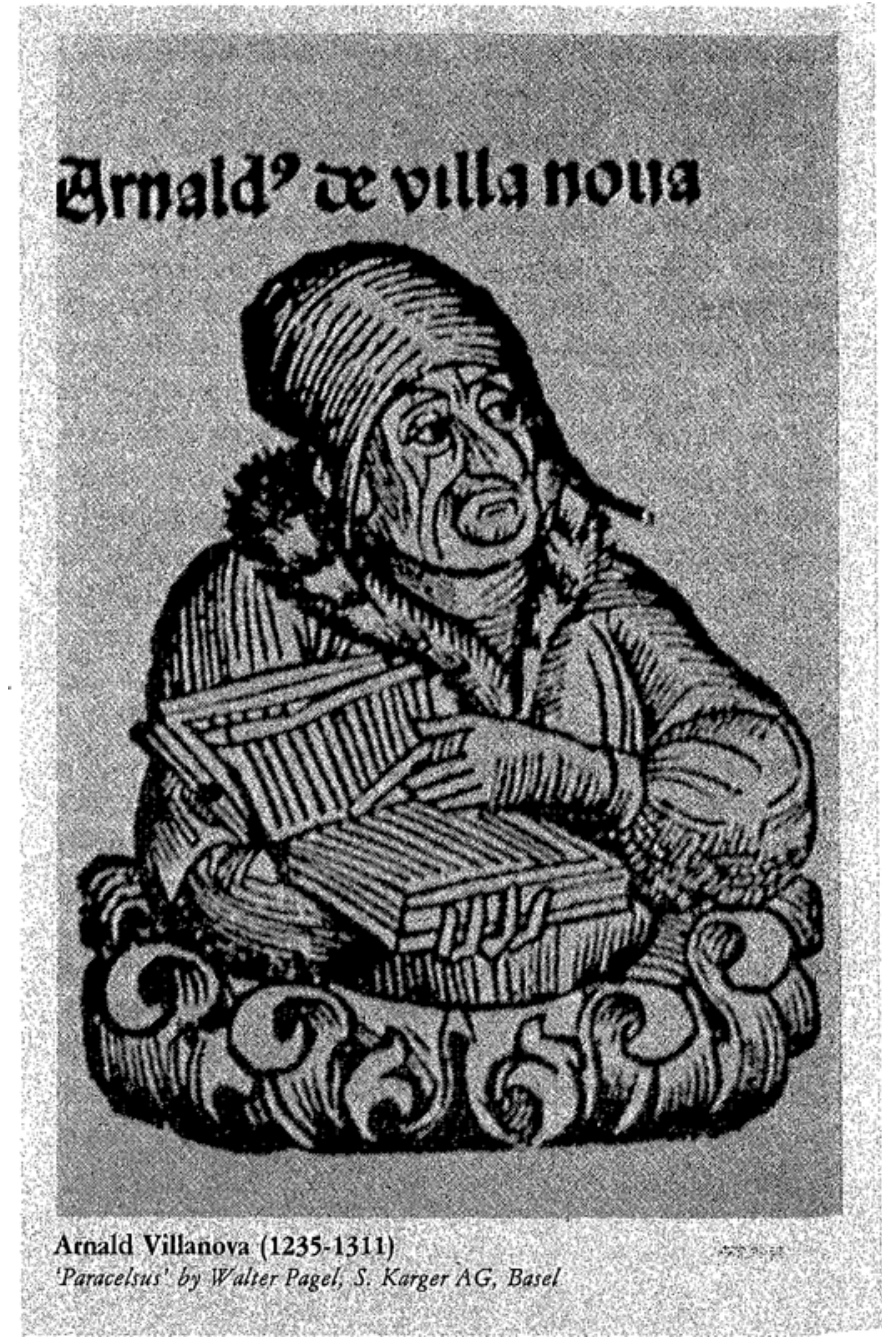

(1235-1315) and other teachers of the era, inspired alchemists of the 14th century to shift away from simply making gold and to search for special elixirs and 'quint essences' (21). The quintessence was the fifth element (in addition to the four basic elements of Aristotle: earth, air, fire and water) responsible for the essential difference between one object or material and another. It contained the special qualities of powers of a substance in concentrated form.

Through elaborate series of dissolutions in strong mineral acids followed by distillations, alchemists of the 14th and 15th centuries hoped to isolate this 'heavenly component' from earthly elements. Many thought that alcohol, yielded by wine, was the universal quintessence (22), while others searched for the elixir of life in the quintessence of blood (23). John of Rupescissa (1360?) tried to add the powers of gold to the quintessence of wine by quenching heated gold leaf in alcohol, a process which he called 'fixing the sun in our 


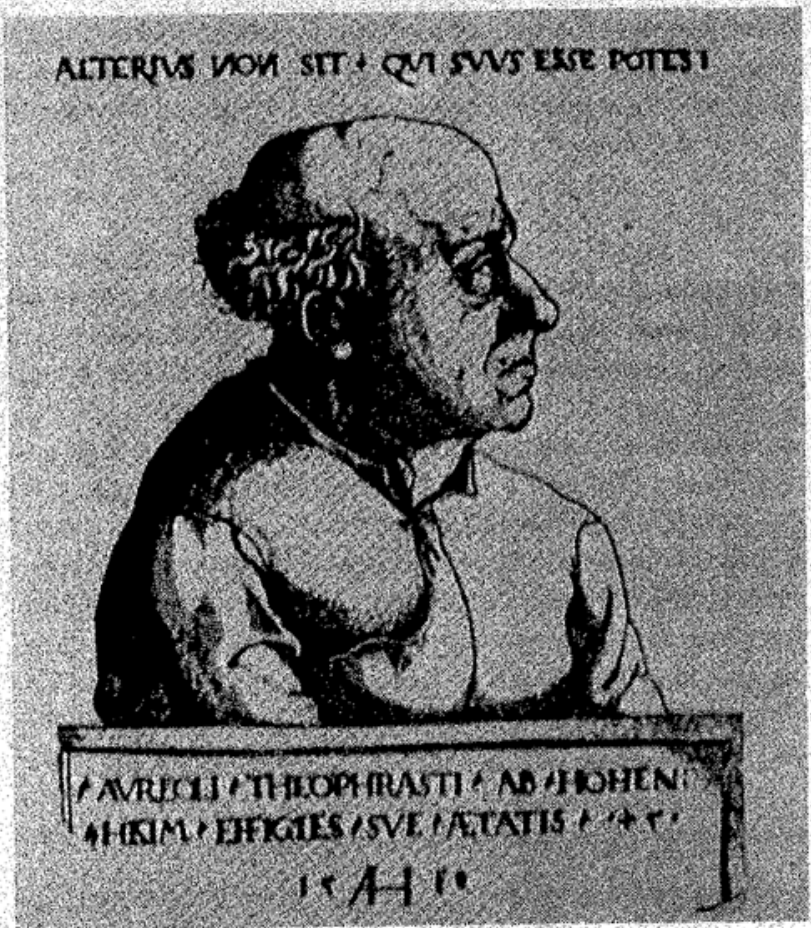

Portrait of Paracelsus. Original by Augustin Hirschvogel, 1538 'Paracelsus' by Walter Pagel, S. Karger AG, Basel sky' (24). This apparent extension of Arnald's recipe for potable gold was copied by many later alchemical philosophers (25).

Even though potable gold did not become a common medicinal preparation until after Paracelsus, debate between advocates and sceptics increased dramatically by the early 16th century. The great Italian metallurgist Biringuccio (1480-1539), sceptical of any kind of alchemy, assured his readers that gold gave warmth to the heart, 'particularly to those who have great sacks and chests full of it' (26), and no matter how many hours they spent preparing their potable gold, those same alchemists 'who exalted it with such high praise are all dead and have not engaged even one period of youth, to say nothing of two or three' (27).

These sceptical views were not shared by Biringuccio's contemporary, the great Swiss medical iconoclast Theophrastus von Hohenheim, or Paracelsus (1493-1541). He took the gist of Bacon's statement one step further, calling on his fellow alchemical philosophers to reject the goal of transmutation of the elements and to embark upon a search for better medicines. Paracelsus cast aside Galencial humoralism and its botanically based materia medica, and replaced them with an ontological concept of disease and an armamentarium of chemically prepared remedies. As part of this approach, he followed Arnald's lead and recommended potable gold as a cure for various ailments. For example, in the treatment of melancholy he prescribed aurum potabile because it 'made one's heart happy' (28). Unfortunately, Paracelsus is not too clear in his method of preparing potable gold, so it is impossible to tell whether or not it contained any gold or, if it did, whether or not it was in an active form (29).

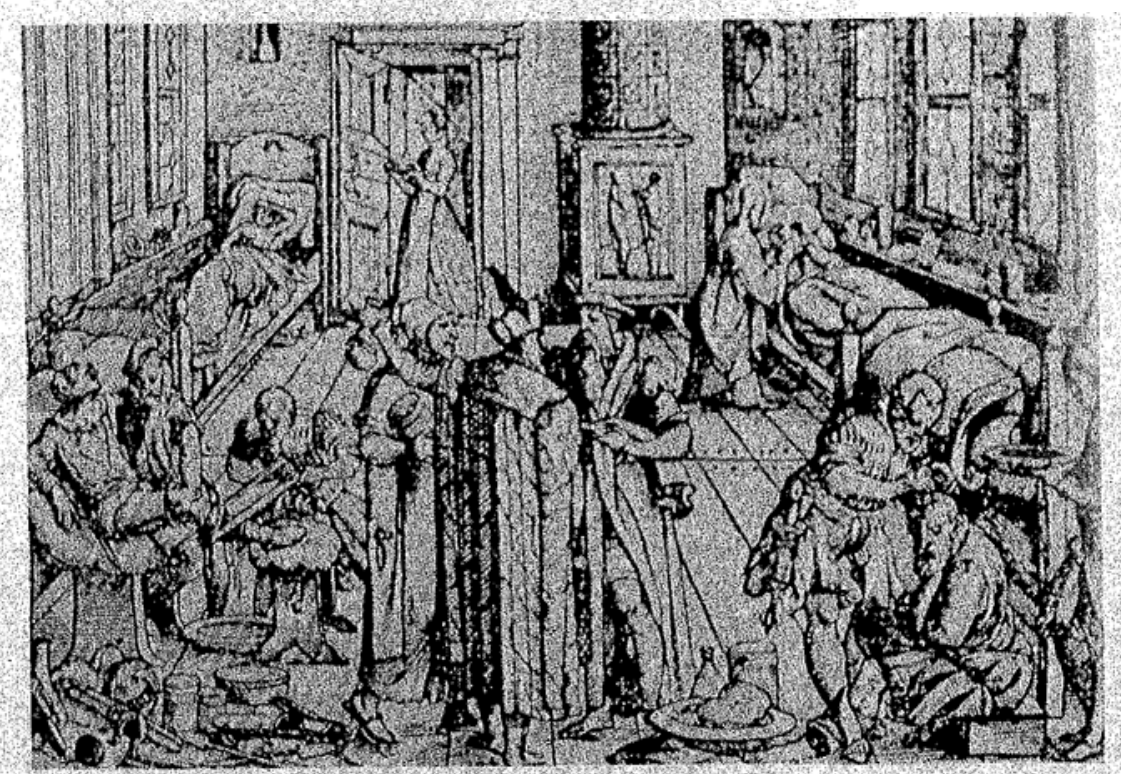

A 16th century hospital scene which contrasts the work of physicians with that of surgeons (on the sides). The figure of Christ is seen in the background comforting the dying patient 'Paracelsus' by W Walter Pagel. S. Karger AG, Basel 
Following the death of Paracelsus in 1541 in Salzburg, large numbers of his writings began to circulate in Europe. A group of disciples, the Paracelsians, emerged in the late 16th century, spreading various versions of his complex theories. Their advocacy for chemically prepared remedies tied them together as a group. They all searched for arcanae, the curing principles that resided deep within all substances. Like their mentor, they depended heavily on distillation, and were preoccupied with the volatile products which resulted therefrom (30).

The serious philosophers and physicians in the Paracelsian ranks were split on the issue of the medicinal value of potable gold. Those who favoured it, such as the German Andreas Libau or Libavius (1540-1616), did so soberly, without extravagant claims (31). Oswald Croll (1580-1609), perhaps the most influential of the group (32), concentrated more on preparations of mercury and antimony than on those of gold (33). Croll's recipes for potable gold are clearer than those of Paracelsus, allowing for some evaluation of their contents. Of his seven recipes, three use aqua regia (thereby producing the soluble salt $\mathrm{AuCl}_{3}$ ) and three use intimate physical mixture, such as grinding gold dust with another powder). Only one of the seven contains no gold, being a version of Arnald's formula. Thus, six of Croll's seven medicines actually contained gold, which was present in a physiologically active form in only three of them (34).

Although the responsible disciples of Paracelsus followed their master in a conservative fashion, there existed a large number of charlatans who capitalized on the notoriety of Paracelsus and his chemical remedies. One such quack, Leonhart Thurneissen zum Thurm (1531-1596) produced 'cosmetics, potable gold, tincture of rubies, amulets and talismans, which he sold at high prices' (35). His rags-toriches-to-rags career was probably typical of the day. In most cases, the 'potable gold' produced by these charlatans contained none of the precious metal. These men were in the medical business to obtain gold, not dispense it (36).

A word must be said about those who opposed the Paracelsians in general and potable gold in particular. The vast majority of educated medical practitioners thoroughly rejected Paracelsianism. These medical men had spent years studying the very books that Paracelsus deemed worthless or fit only for a bonfire. No wonder that one such critic called him 'an evil magician, atheist, and pig' (37). Some of these conservatives argued that the internal consumption of gold was dangerous and would cause permanent damage. Others, such as the famed French pottery maker and public lecturer Bernard Palissy (1510-1589), attempted to refute the efficacy of potable gold from within the confines of alchemical theory and reasoning (38).

In summary, as the 17th century approached, European

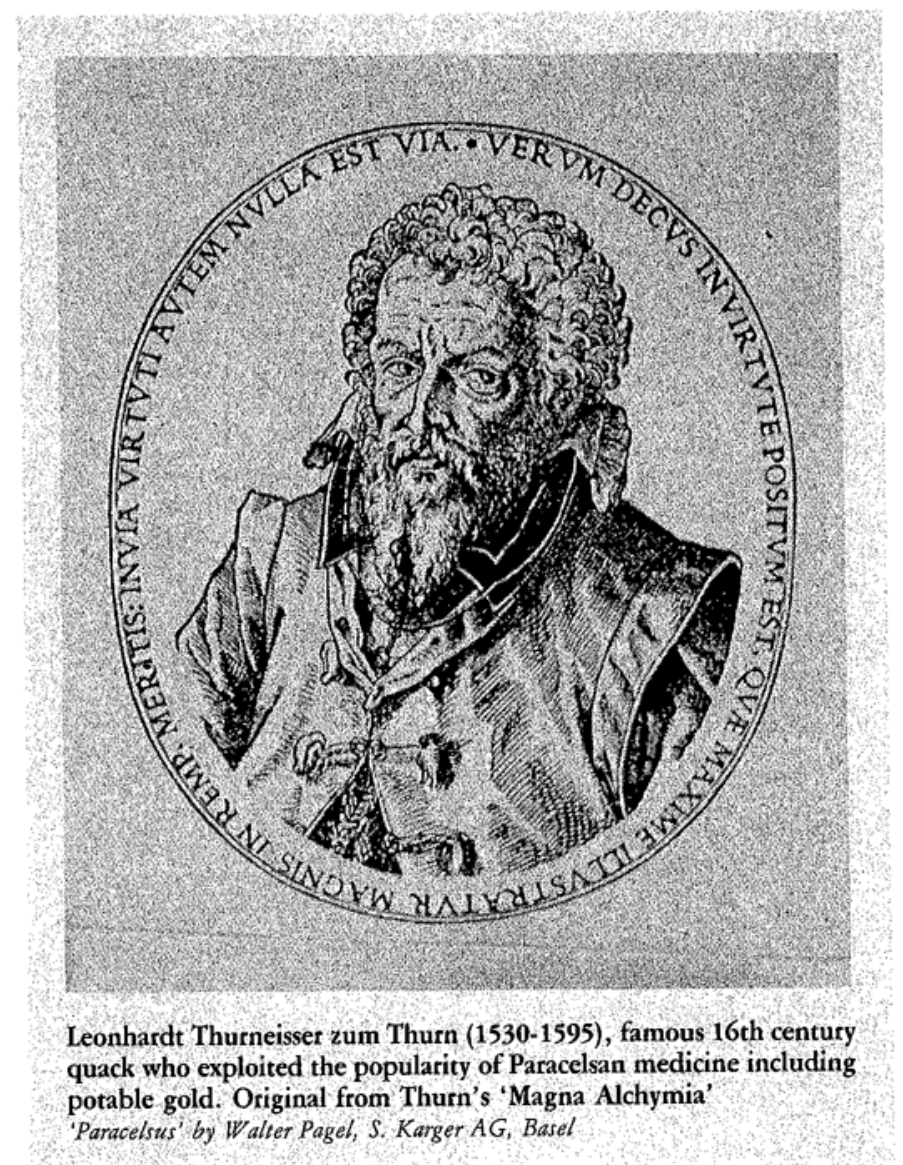

medical practitioners had begun to discuss vigorously the value and dangers of chemically prepared medicines. Potable gold, touted by some as the elixir of life, was a prominent topic in these discussions. The large number of so-called gold compounds that failed to contain any gold or contained it in an inert form muddled the already chaotic debate. Nevertheless, the 17 th century brought some degree of standardization to the preparation of many remedies, including those based on gold, and this facilitated their rational evaluation.

\section{The Seventeenth Century}

In the early 17 th century, gold began entering the official drug compendia (pharmacopoeias). Under the influence of German alchemists, especially Croll (39), Germanic pharmacopoeias accepted several different gold preparations (40). In England, the first 'Pharmacopea Londinensis' listed gold as an essential medicinal article (41).

Just because gold or any other medicament entered a pharmacopoeia of that time does not necessarily mean that it was commonly used by physicians. These early modern drug 

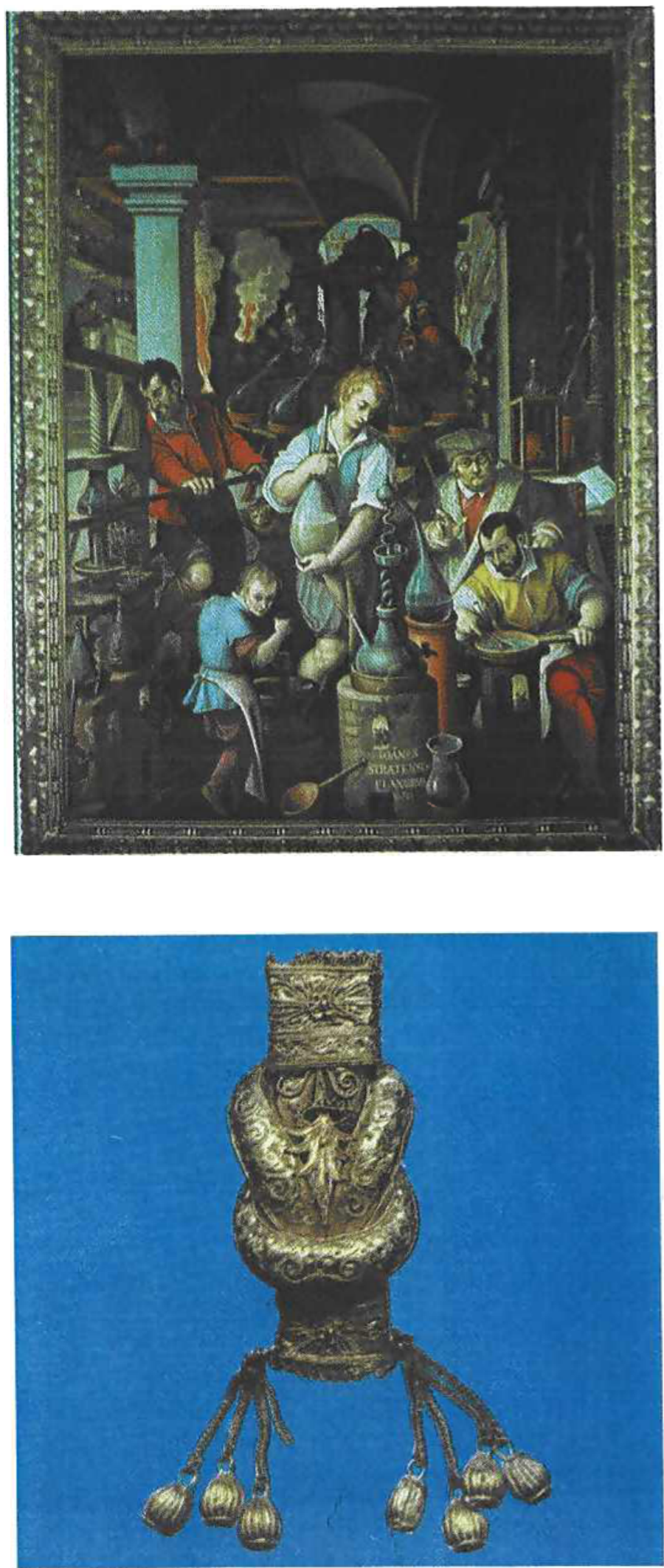

'The Alchemist' by Joannes Stratenus (fl. 1570). The layout of the laboratory is based on Biringuccio's 'Pirotechnia' (1540)

'Art and Pharmacy III' by D.A. Wittop Koning, Ysel Press, Deventer, Holland, 1964

compendia were catch-alls and included new drugs in their listings along with many old outdated preparations. Although the medicinal use of gold produced a great volume of polemical literature in the 17 th century, authoritative 18th century commentators agree that the general medical practitioner of their time did not use it, and that quacks served as its champions (42).

By the mid-17th century, gold advocates had developed elaborate rationales for its supposed efficacy. Most centred on the 'cordiality' of gold, which meant its soothing or salutary effect on the heart. This approach clearly descended from the alchemical belief that gold represented the power of the sun on earth, and that the heart was the physiological equivalent of the sun, the body warmth (43). Nicholas Culpeper put these sentiments into a little doggerel verse (44):

\section{'For Gold is cordial And that's the reason Your raking misers Live so long a season."}

Yet, Culpeper seriously supported the medicinal use of gold and published a small book on the subject. As a cordial, Culpeper saw gold as useful in any ailment caused by a decrease in vital or animal spirits (seen as arising in the heart). These included melancholy, fainting, fevers and falling sickness (45). Oddly enough, Culpeper purposely avoided recommending any one preparation of gold over another, and provided no recipes (46).

The common preparations of medicinal gold from this period fall into three categories. The most popular one, aside from the quack remedies, involved dissolution of elemental gold in aqua regia. The solution was then heated, driving off the solvent. The resulting salt, $\mathrm{AuCl}_{3}$, could be redissolved in the desired vehicle or heated to produce a fine gold powder suitable for the production of colloidal gold. In addition, the caustic gold chloride could be made into pills with a suitable excipient and coated with gold leaf (47).

A second popular preparation, fulminate of gold, was made in the same way as gold chloride, except for the substitution of sal ammoniac for the hydrochloric acid of

A small bezoar stone set in gold, probably to be used as an amulet. The stone was much valued for its supposedly protective action against poisons 'A History of Drugs' by Lydia Mez-Mangold, Hoffmann LaRoche \& Co., Basel 
aqua regia (48). Physicians prescribed the fulminate for its diaphoretic qualities as well as its 'cordiality'. Its use was even more limited than that of other gold compounds, because of its explosive nature and its apparent toxicity (48).

Potable gold products that contained no gold, made up the third category. These were mainly left-overs from alchemical preparations of 'quintessences' or 'arcanae'. Composed of products of the distillation of gold solutions or supposed gold solutions, the resulting remedies were touted by advocates as panaceas (49).

By the late 17 th century, physicians had decided that these preparations were either too corrosive (gold chloride), too dangerous (gold fulminate) or inert (colloidal and alchemical preparations). The rise of scientific chemistry under the influence of men such as Johann Glauber (1604-1679), Robert Boyle (1627-1687) and Nicolas Lemery (1645-1715), had dispelled the alchemical nonsense concerning medicinal gold. From within this new rational framework, physicians of the late 17 th century generally opposed gold remedies.

The opponents of gold remedies had a hard time convincing the public. As one physician put it: 'It is but swimming against the stream, to tell them, gold, any way prepared, is not so much a cordial, as it was in their pockets' (50). In response, proponents of gold used the timehonoured technique of publishing testimonials from cured patients. Opponents responded in kind with pamphlets full of poisonings from the same medicines (51). The talented physician and chemist Robert Boyle was partially convinced of gold's medicinal powers by some testimonials. Still, he felt that 'blew vitriol' (copper sulphate) offered much more to medical practitioners than did gold or silver. Commenting in his 'Specifick Medicines' on the use of gold, Boyle says that preparations of the metal were in decline and 'little compounded' (\$2).

\section{The Eighteenth Century}

The medicinal use of gold, never extensive since its introduction by the alchemists, dropped to almost nothing during the 18 th century. As the eminent Dutch physician Hermann Boerhaave (1668-1738) put it in one of his lectures:

'[Gold is] well known in the world, but of little use in medicine, except for ostentation. Leaf-gold was supposed once to have virtue, but the stomach does not act upon it. The powder called Pulvis Fulminans [gold fulminate] is only a curiosity ... Aurum Potabile, or a Tincture of Gold, has been also idly called a medicine. But the present practice wisely rejects both.' (53)

An examination of the 'Pharmacopoeia Pauperum or The Hospital Dispensatory' (London, 1718) supports Boerhaave's contention. Even though this small formulaty claims to contain 'the recipes of the most eminent physicians in our

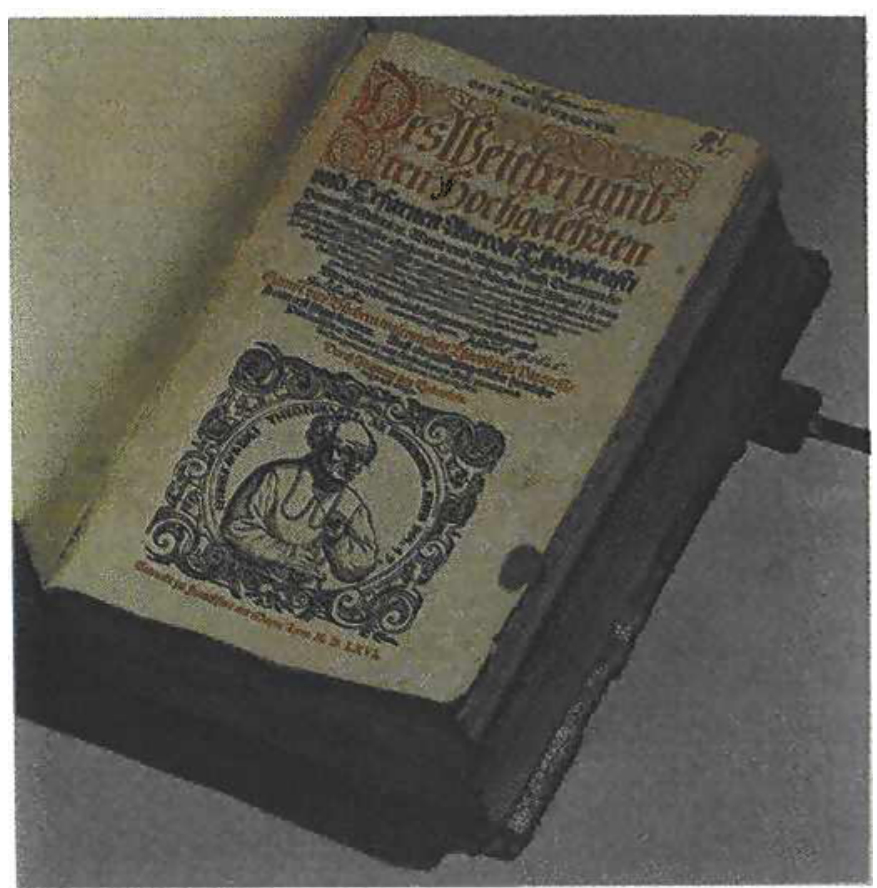

Title page from a book on wounds and drugs by Paracelsus

'A History of Drugs' by Lydia Mez-Mangold, Hoffmann LaRoche \& Co., Basel. Photograph by P. Herman, Basel

Gold amulet of the type often used, for instance, as a cure against warts

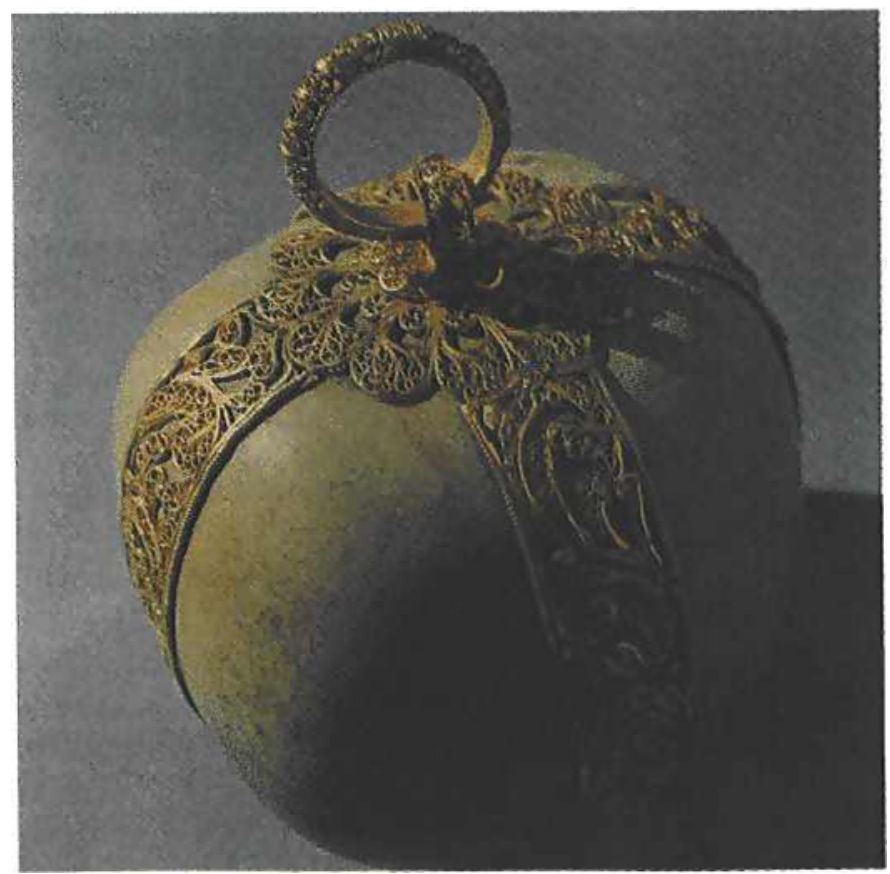




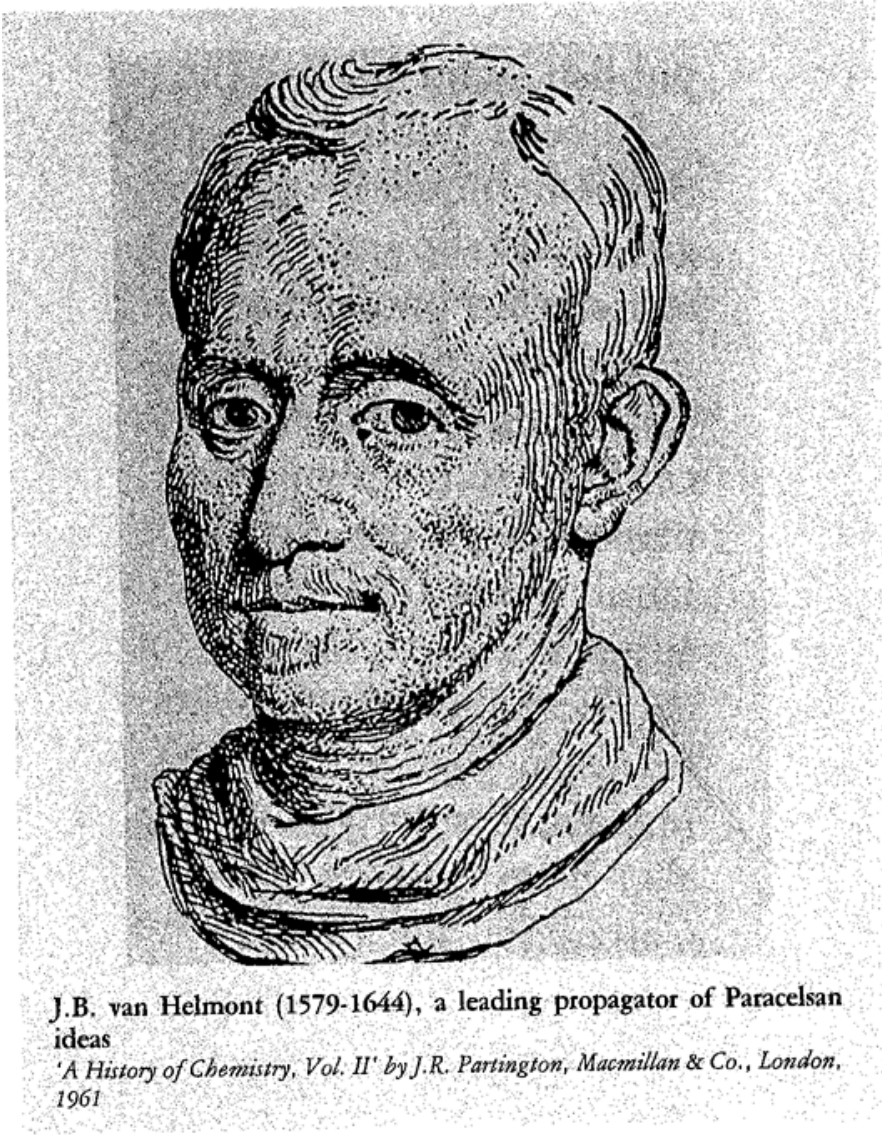

nation' and included mercury and antimony preparations, gold is not mentioned (54).

Finally, Robert James in his mammoth 'Medicinal Dictionary' summarized the reputation of gold in the 18th century in this manner:

"The virtues of the chemical preparations of gold are...dubious, because they seem to derive their energy, not from the gold, but from the menstrua, and other substances mixed with it. Whence we may conclude, that the most valuable and most precious of all metals is the most useless in physic, except when considered as an antidote to poverty.' (55)

By the end of the 1700 's, the place of gold in therapeutics had reached such a low point that the great medical systematizer, William Cullen, failed even to mention it in his 'Treatise of the Materia Medica' (56).

\section{The Nineteenth Century}

By the early 19th century, many pharmacopoeias had dropped gold from their lists of drugs, or only included gold leaf for pill gilding (57). In 1811, a French physician from Montpellier, J.A. Chrestien, published a book that aimed to change that situation (58). Chrestien had experimented with the external administration of medicaments for the treatment of internal diseases. This consisted of rubbing the powdered drug on blistered skin or the gums and tongue. Working in the favourable clinical milieu of post-revolutionary France, Chrestien was able to evaluate seriously the therapeutic effects of several drugs, including preparations of gold. He tried five different preparations of gold, including its fulminate and chloride, before settling on 'muriate of gold and soda' as his favourite compound (59). By mixing sodium chloride with gold chloride, a less caustic, apparently therapeutically active agent resulted.

Chrestien used this double chloride of gold in the treatment of syphilis, reasoning that it might have an action similar to that of mercury. He reasoned that since gold was heavier than mercury, it might prove more efficacious against syphilis (60). After clinical testing, Chrestien concluded that gold was slightly superior to mercury in the treatment of secondary syphilis and produced significantly fewer side effects. After his success against syphilis, he tried the double chloride on patients of other diseases and reported curing a case of goitre and a case of scrofula (61).

Soon after the publication of Chrestien's experiments with the double chloride of gold, New York Hospital began testing the new syphilis treatment. Samuel L. Mitchill, the eminent New York physician, had sent a copy of Chrestien's book to his colleagues at this hospital (62). Under the supervision of Valentine Seaman, of Queen's College, John C. Cheesman, a medical student at the college, wrote his MD dissertation on the efficacy of gold therapy in syphilis (63).

This short, 28-page work describes the case histories of seven syphilis patients treated along the lines of Chrestien's new method. (Even though Cheesman calls the agent used 'muriate of gold', which is gold chloride, a look at the preparation of the agent reveals that it was actually the double chloride of gold and sodium (64).) The supervising physician, Dr. Seaman, also administered the gold preparation to a few scrofulous patients, but without success (65). In most cases the double chloride was administered in doses of $1 / 15$ th grain $(4 \mathrm{mg}$ ), once or twice daily in the form of a pill (66).

Characterizing this as the 'first' employment of gold therapy in the United States, Cheesman commented that 'from the results of these experiments ... we may safely conclude with Dr. Seaman, that "we have indeed seen mercury dissolved of half its honours, of its proud preeminence as the only remedy in syphilis", having now ample proof of the equal power of gold over that most dreadful disease' (67).

As was the case in earlier times, this new medicinal use for gold was met with disbelief and opposition. When others 
tried to reproduce Chrestien's results, they met with failure. An Edinburgh physician, reviewing Chrestien's book, concluded that 'our trials, so far as we have carried them, do not confirm M. Chrestien's statement of the activity of gold upon the animal economy' (68). In addition, it appears that the syphilitics 'cured' at New York Hospital had to come back for treatment, because their symptoms returned (69). Finally, some authorities expressed concern over the toxicity of the touted preparation (70).

Even with this negative evidence, gold salts returned to official compendia. In the 'United States Pharmacopoeia' of 1820 the double chloride of gold appears under the title 'Muriate of Gold', the name which was given to it at New York Hospital (71).

Stimulated by the work of Chrestien, physicians began experimenting with different gold preparations, resurrecting some of the old, rejected gold compounds and creating a few new ones. French physicians, following the lead of their countryman, supported the new remedies with the most vigour. While the 'United States Pharmacopoeia' at midcentury gave official status to only the double chloride of gold, the French equivalent, the 'Codex Medicamentarius seu Pharmacopoeia Gallica', contained six different official preparations of gold (72). Even the explosive fulminate of gold returned to the physician's armamentarium (73).

By the mid-19th century, after this brief spurt of experimentation, the double chloride - the favourite of Chrestien - became the dominant form of gold used by medical practitioners (74). The 'United States Dispensatory' of 1843 advised its readers to prescribe $1 / 12$ th grain $(5 \mathrm{mg})$ of the double chloride in the form of lozenges or pills. In addition, a version of Chrestien's method was given which called for gradually increasing doses of the double chloride, from $1 / 15$ th to $1 / 8$ th grain ( 4 to $8 \mathrm{mg}$ ), rubbed into the tongue and gums (75).

Unlike the debates of the 16th and 17th centuries, the increasing use of gold in syphilis therapy did not produce volumes of polemics. Syphilis, in contrast to ambiguous ailments like melancholy, was a well-known disease entity. Since its appearance in the late 15 th century, physicians had tried scores of 'wonder cures' and had concluded that only mercury and its salts offered any hope. The toxicity and numerous side effects of these mercurials caused medical men to search for better treatment methods and drugs. Physicians learned to try any new treatment and to wait patiently for it to fail. Jonathan Pereira, an English authority on materia medica, spoke favourably of the double chloride in the treatment of syphilis, but cautioned: 'A more extended experience of it is, however, necessary to enable us to speak of its remedial powers with confidence' (76).

During the second half of the 19th century, European

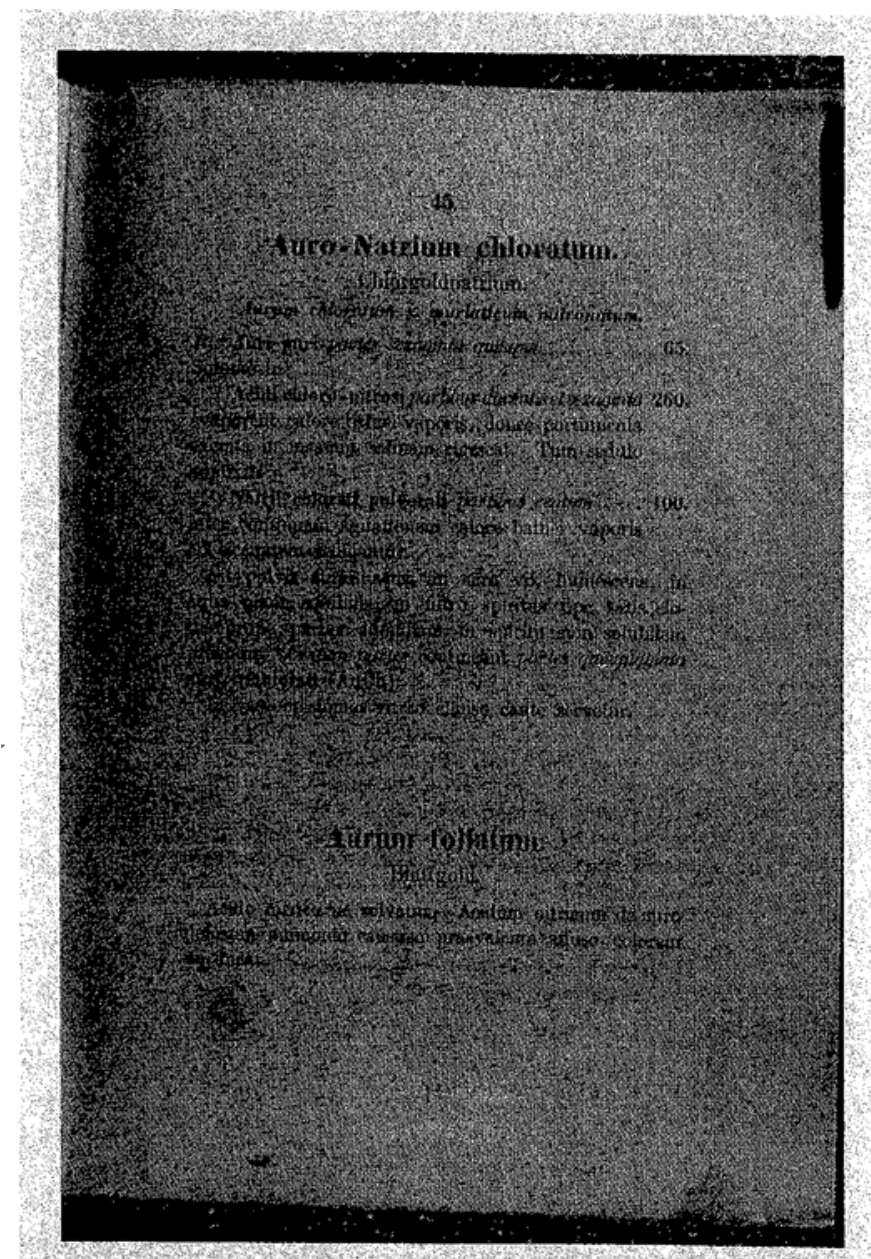

A page from Pharmacopoea', 1872, showing how the double chloride' of gold had achieved prominence among gold preparations by the mid-19th century

physicians continued to prescribe gold preparations, in an ever-widening number of circumstances. In contrast, the interest of American medical practitioners in gold waned until the 1890's (77). At that time, American physicians jumped on the gold bandwagon, encouraged by the favourable reports from Europe (78) and stimulated by stories coming out of a small town southwest of Chicago.

\section{Dr. Keeley and the Keeley Gold Cure}

Dwight, Illinois, was the home of Leslie I. Keeley and his Keeley Institute - both committed to the rehabilitation of alcoholics. Keeley, the son of a New York country doctor, received his medical degree in 1864 at the age of 32 . He subsequently joined the Union Army serving as an assistant surgeon. In the army, Keeley observed the destructiveness of alcoholism on a massive scale, watching thousands of bored, 


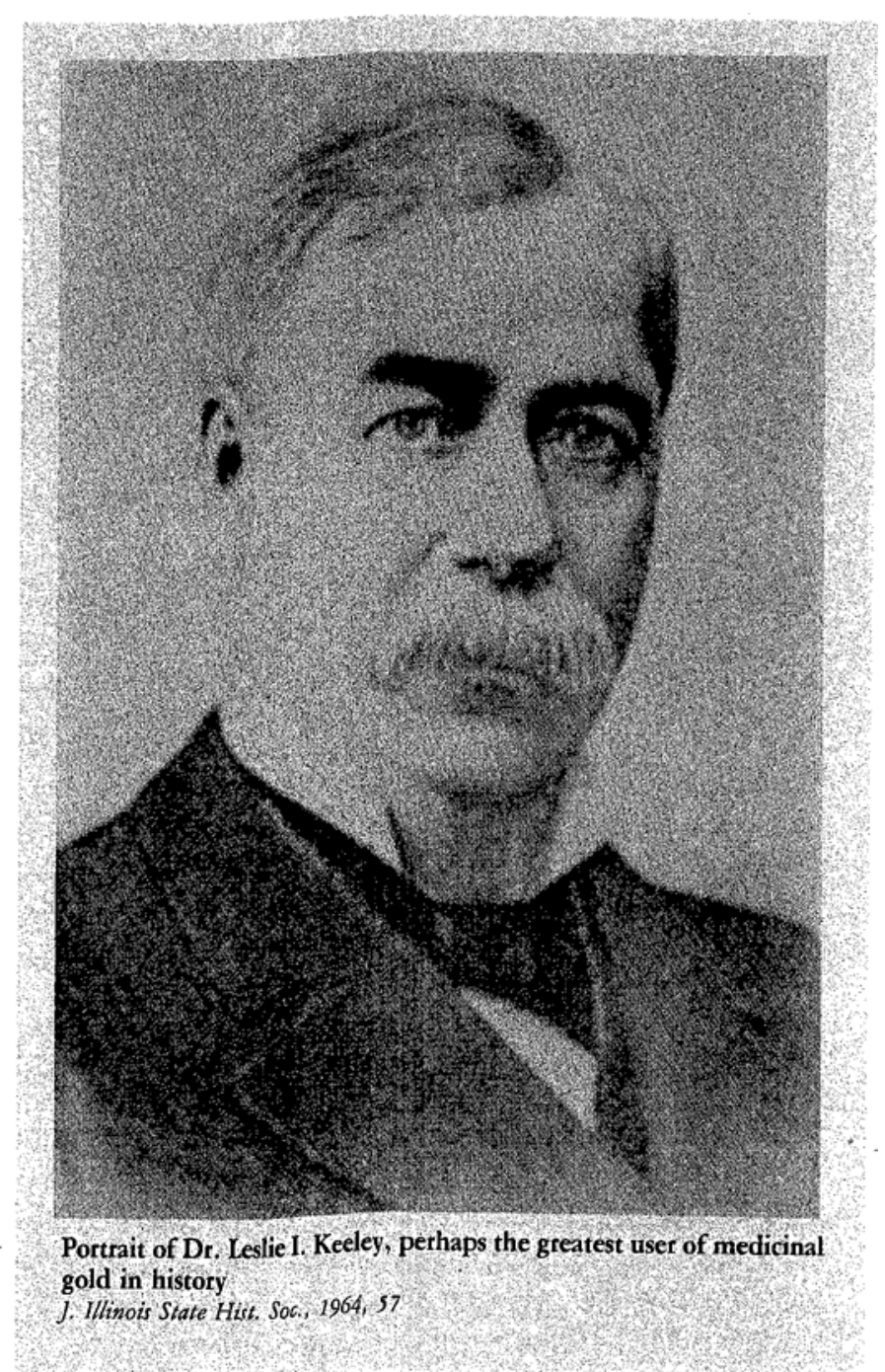

depressed soldiers attempt to drink their troubles away. After the war, Keeley settled in the sleepy town of Dwight and began his search for an alcoholism cure. Working with local pharmacist, John R. Oughton, Keeley reportedly looked for over twelve years before he settled on the double chloride of gold as his 'cure'. As Keeley put it in the local paper: 'Drunkenness is a disease and I can cure it' (79).

Keeley replaced the strait jacket horror of most alcoholism asylums with a cordial atmosphere of cooperation. His first small sanatorium, opened in 1880 , relied on moral suasion and multiple injections of low doses of the double chloride. Gradually, the fame of the Institute grew, and patients poured in from around the country, especially from Chicago and other midwestern cities (80).

Keeley's Institute received national attention when the good doctor challenged Joseph Medill, publisher of the
Cbicago Tribune, to send him 'six of the worst drunkards [in Chicago], and in three days I will sober them up and in four weeks I will send them back ... sober men ... who will never seek liquor' (81). The sceptical Medill agreed and sent down 'a half dozen of the toughest products of alcoholism which the Chicago saloons had been able to turn out ...' The result? According to Medill, 'they went away sots and returned gentlemen' (82).

The fame of Keeley's cure spread, and physicians and clinics opened franchise branches of the Institute across the country in the early 1890's (82). Although it is difficult to estimate the number of patients treated with the double chloride of gold, this may have been as high as 100000 (83). By the mid-1890's, over 30000 former 'Keeley Cure' patients joined the Bi-Chloride of Gold clubs that sprang up after 1891. These clubs were dedicated to the twin goals of mutual support and spreading the gospel of Dr. Keeley's marvellous gold treatment.

After Keeley's death in 1900, the Institute passed into the hands of Keeley's pharmacist partner, John Oughton. Control of the Institute has remained in the hands of the Oughton family ever since (84). After Dr. Keeley's demise, the use of the double chloride seems to have halted, and treatment methods became more like those of Alcoholics Anonymous (85).

More historical research on the Keeley Institute and its gold cure is needed. When asked for details concerning his dosage regimen, Keeley simply shook his head and pointed to the disaster that befell Robert Koch and his tuberculin treatment. Pressured into announcing prematurely his new tuberculosis therapy, Koch later received the scorn of a disillusioned public when it failed. Wishing to avoid a similar stituation, Keeley apparently took to the grave the exact formula of his alcoholism cure. This is unfortunate, because the Keeley Institutes probably administered more medicinal gold than anyone before or since (86).

Dr. Keeley's gold cure for alcoholism exemplifies a trend of late 19th century therapeutics. Confronted by a group of seemingly incurable diseases - tuberculosis, diabetes, syphilis and epilepsy - medical practitioners tried almost any new drug or treatment which they could get their hands on. In addition to these illnesses, physicians used gold compounds in cases of morphine addiction, premature senility, nephritis (87), anaemia (88), neurasthenia (89), lupus (90) and even chronic dyspepsia (91). Yet, as one authority put it, there was a great deal of 'damning [gold] with faint praise'. In all these indications, gold appeared to be only a secondary drug, a back-up if the standard treatment failed. Few doctors prescribed the drug, and 'only a very small minority' employed it with any regularity (92).

In addition to the old double chloride, gold bromide 
received a measure of support in Europe and America. Supposedly, this compound combined the 'nutritive' powers of gold with the sedative effects of a bromide. The nutritive qualities of gold preparations arose supposedly from their escharotic effect on the gastro-intestinal tract, which allowed increased absorption of foodstuffs. This explained the apparent efficacy of the drug in cases of anaemia, neurasthenia, diabetes and other 'constitutional' disorders which at the time were treated with 'alterative' drugs (93). In cases calling for the bromides, especially epilepsy, gold bromide appeared to exert the desired effect before a recipient would develop the serious side effects associated with 'bromism' (94).

In some ways, this late 19 th century expansion of use for gold differed little from the speculations of the late Renaissance. Instead of 'calming the archeus of the stomach' as a 17 th century Helmontian might have attempted to do with aurum potabile, some late 19 th century physicians hoped to cure anaemia via the 'alterative powers in nutrition' of gold. Clinical trials were usually a matter of giving a selected treatment to a handful of patients: if they got better, the treatment worked; if they got worse, it did not. This was not just the case with gold, but with all drugs and remedies. Conclusive testing techniques - specifically the controlled clinical trial - came in the 20th century. Only then was gold's medicinal utility realized.

\section{Robert Koch and the 20th Century}

Today, the medicinal use of gold is limited almost entirely to the treatment of rheumatoid arthritis. The source of this therapeutic method can be traced back to Robert Koch's discovery in 1890 of the in vitro bacteriostatic properties of gold. He found that a solution of gold cyanide, at a concentration of only $0.5 \mathrm{ppm}$ inhibited the growth of the tubercle bacillus (95). Clinicians, captivated by the achievements of immunology, generally ignored this finding until after the success of Ehrlich's new chemotherapeutic agent, SALVARSAN (around 1910). As Keers has pointed out, gold therapy in tuberculosis rose in popularity through the 1920's and 30's and declined after controlled clinical trials had demonstrated its inefficacy (96).

However, in the late 1920's, the mistaken belief that the tubercle bacillus caused rheumatoid arthritis led Forestier and others to try gold in the treatment of that ailment. After 30 years of medical debate the 1960 report of the British Empire Rheumatism Council finally confirmed that gold is of significant value in the treatment of rheumatoid arthritis (98).

One other medicinal use of gold in the 20th century should be mentioned in passing. This is the role of radioactive gold-198 in the treatment of malignancies. Introduced by P.F. Hahn and his associates, colloidal gold -198 is particularly

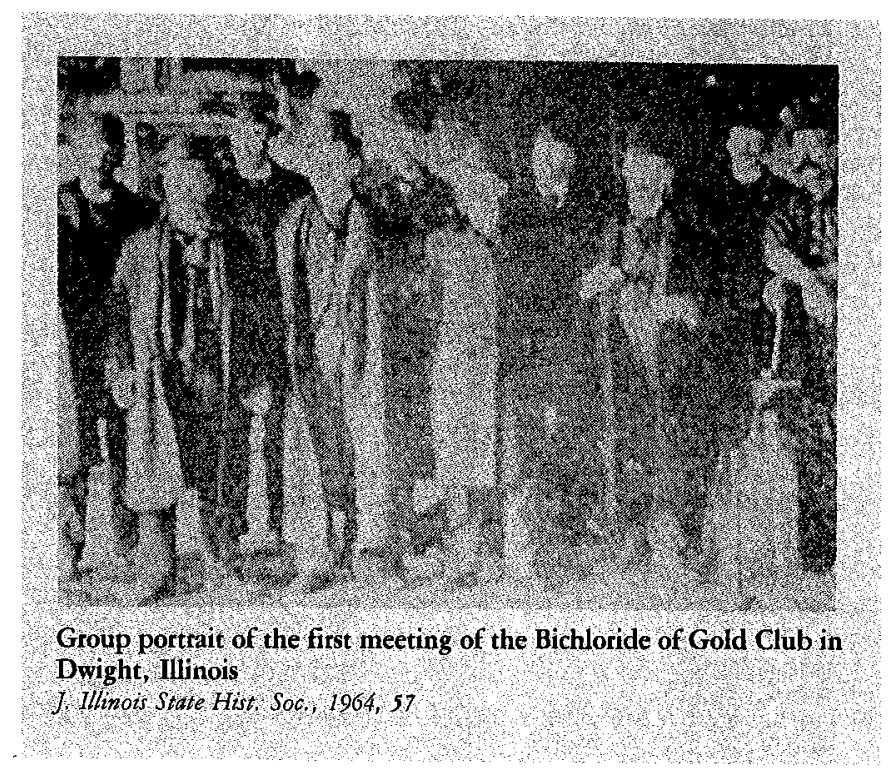

suited to intracavitary administration: it is chemically inert inhibits the formation of cavity fluid and has a relatively shor half-life (99). In addition, gold-198 has proven useful as ar interstitial implant. Because of its short half-life (2.7 days) radioactive 'seeds' may be safely left in the patient right nex to the tumour. Although gold-198 colloid is still used todas intracavitarily as a 'neoplastic suppressant', other radio. isotopes, notably iridium-125 and iodine-125, have replacec it as an interstitial implant (100).

The history of the medicinal use of gold has spanned the centuries and has followed in parallel the progress of medicine from superstition to modern science, from amulet: to nuclear physics. This review has concentrated on the use o: gold before 1900 , a period during which physicians sought ir vain a medical application for 'the most noble of metals' Beyond all the humorous remarks concerning the soothing action of gold on the itching palm, the medicinal use of the metal has served as an important focus for medical debate research and discovery.

\section{References}

1 P. Smit, Proc. Mine Med. Off, Assoc, 1968, 47, 91

2 H. E. Sigerist, 'A History of Medicine', Vol. I, New York, 1951, p. 283 A. C. Wootton, 'Chronicles of Pharmacy', Vol. I, 1910, reprinted Tuckahoe, N.Y., 1972, p. 40

3 See Sigerist (2), pp. 471-477

See (1)

4 G. F. Most, 'Enzyklopädie der gesammten Volksmedizin', Graz, 1973. pp. 242-243

W. Hand, 'American Folk Medicine', Berkeley, CA., 1976, p. 176

5 W. H. S. Jones, transl., 'Hippocrates', Vol. I, II and III, London, 1923 G. Marks and W. K Beatty, 'The Precious Metals of Medicine', New York, 1975, p. 27 
6 R. Multhauf, Bull. Hist. Med., 1954, 28, 101-126

W. G. Spencer, transl., 'De Medicina of Celsus' .Vol. I, II and III, Cambridge, MA. 1938

7 K. C. Bailey, 'The Elder Pliny's Chapters on Chemical Subjects' .. Vol. I, London, 1929 , p. 104

8 See (7)

9 W. Pagel, 'Paracelsus', Basel \& New York, 1958, pp. 201 and 287

10 M. Levy, transl., 'The Medical Formulary of Aquábádhín or Al-Kindi', Madison, WI., 1966 , p. 234

11 W. Kirkby, Chem. Drug., 1939, 130, 682

G. E. 'Trease, 'Pharmacy in History', London, 1964 p. 235

G. Urdang, "Zur Geschichte der Metalle in den amtlichen deutschen Arzneibüchern', Mittenwald, 1933, p. 15

12 W. Schneider, 'Lexicon zur Ánzneimittelgeschichte', Vol. IV Frankfurt, 1970 , p. 55

13 J. M Stillman, 'The Story of Alchemy and Early Chemistry', New York, 1924 , reprinted 1960 , p. 266. For an example of Bacon's influence see Oswald Croll, 'Philosophy Reformed and Improved', transl. H. Pinnell, London, 1657, pp. $91 \mathrm{ff}$.

14 See Stillman (13), p. 190

15 R. Multhauf, Bull. Hist. Med. 1956, 38, 329

16 See Stillman (13), p. 285

17 Sec (9), p. 249

18 See (9), p. 254

19 See (9), P. 256

20 L. Thorndike, 'A History of Magic and Experimental Science', Vol. II New York, 1923 , p. 857

21 See (15), 344

22 See (9), pp. $264 \mathrm{ff}$.

23 See (9), p. 264

24 R. Multhauf, ISIS, 1954, 45, 364

25 J R. Partington, 'A History of Chemistry', Vol. II, 1961, pp. $85-86$

26 V. Biringuccio' 'De La Pirotechnia', 1540, transl. C. S. Smith, New York, 1942 , p. 27

27 See (26), p. 39

28 T. von Hohenheim [Paracelsus] 'Von den Krankheiten, die der Vernunf berauben', in 'Sämtliche Werke', ed. K. Sudhoff, Vol. II, Munich and Berlin, 1930 , p. 452

J. Starobinski, 'History of the Treatment of Melancholy', New York, 1972 , p. 38

29 See Stillman (13), p. 315

30 See (15), 339

31 See $(25)$, p. 255

32 G. Urdang Arch. Int. Hist. Sci., 1954, 7, 311

33 See $(6), 117 \mathrm{ff}$

34 See (6), 117

35 See (25), pp. $152 \mathrm{ff}$. and (9), pp. $195 \mathrm{ff}$.

36 H. A. Sampson, ISIS, 1943, 34, $472-496$

37 See (25), pp. $156 \mathrm{ff}$. and (9), pp. 311-333

38 'Oeuvres de Bernard Palissy', ed. F. St Fond, Paris, 1777, pp. 363-374

$39 \mathrm{G}$ Urdang, Arch. Int. Hist. Sci., 1954, 7, $306 \mathrm{ff}$

40 See Urdang (11), pp. $71 \mathrm{ff}$.

41 'Pharmacopeia Londinensis of 1618', facsimile, ed. G. Urdang, Madison, WI, $1944, p, 46$

42 R. James, 'A Medicinal Dietionary,. ' Vol. I, "London, 1743, no pagination: under rubric 'AUR'

43 See (36), 487

E. Bolnest, 'Aurora Chymia...', London, 1672 , p. 99

$44 \mathrm{~N}$. Culpeper, 'Pharmacopoeia Londinensis; or the London Dispensatory. ', London, 1672 , p. 51

45 See (44), pp. $51 \mathrm{ff}$.

46 See (44), p. 212

47 K. Digby, 'Choice and Experimented Receipts', London, 1668 , pp. $194 \mathrm{ff}$

See (25), pp. $355 \mathrm{ff}$

T. Thomson, 'History of Chemistry', Vol. I, London, 1830 , p. 228

48 See (42); and (25), pp. $278 \mathrm{ff}$

49 See $(42)$

50 W. Harris, 'Pharmacologica Anti-Empirica; ...', London, 1683, p. 42

51 F. Anthony, 'The Apologie or Defence of. . . A Medicine called Aurum Potabile', London, 1616

52 R. Boyle, 'Of the reconcileableness of Specifick Medicines...' London, 1685, p. 183

53 H. Boerhaave, 'Materia Medica. ', London, 1755

54 R. Coatsworth et al., 'Pharmacopoeia Pauperum or the Hospital Dispensatory', London, 1718 , pp. 3, 15 and 16
55 See $(42)$

56 W. Cullen, 'Treatise of the Materia Medica', Vol. I and II, Philadelphia, PA., 1808

57 'Pharmacopoeias of the London, Edinburgh and Dublin Colleges', ed. J. Thomson, Edinburgh, 1815, pp. 6, 94 and 180

58 J. A. Chrestien, 'De la Méthode Iatraleptique; ou Observations...' Paris, 1811. I was unable to obtain this work and so relied upon the following teview: Anon., Edinburgh Med. Surg. J., 1815, 11, 239-243

59 See (58), $240 \mathrm{ff}$.

60 See $(58), 240$

61 See $(58), 243$

62 J. Cheesman, 'On the Medicinal Properties of Gold', New York, 1812, p. 20

$63 \operatorname{Sec}(62)$, p. 2

64 See $(62)$, pp. $16 \mathrm{ff}$

65 See $(62)$, p. 28

66 See (62), pp. 21-28

67 See (62), p. 28

68 See (58), 243

69 J. R. Coxe, 'The American Dispensatory', 7th Ed., Philadelphia, PA., 1827, p. 127

70 G. B. Wood and F. Bache, 'The Dispensatory of the United States of America', Philadelphia, PA., 1834, p. 1086

71 'Pharmacopoeia of the United States of America', Boston, MA., 1820 , 89

72 G. B. Wood and F, Bache, 'The Dispensatory of the United States of America', 5th Ed., Philadelphia, PA., 1843, p. 1257

73 J. Pereira, 'The Elements of Materia Medica and Therapeutics', 2nd Ed., London, 1842, p. 685

74 See $(73)$, p. $684 ;$ and $(72)$, p. 1258

75 See $(72)$, p. 1258

76 See $(73)$, p. 684

77 A. Stille and J. Maisch, 'The National Dispensatory', 2nd Ed., Philadelphia, PA., 1879 , p. 263

S. Percy, Am. Med. Times, 1862, 4, 75-76

78 W. H. Walling, Med. Surg. Rep., 1895, 72, 121-122 and 1897, 76, 198-199

79 G. A. Barclay, J. Illinois State Hist. Soc., 1964, 57, 344

80 See (79), 346

81 See $(79), 347$

82 See (79), 347

83 See $(79), 351$

84 See $(79), 364$

85 See $(79), 364$

86 See (79), 354

H. W. Morgan, 'Drugs in America: A Social History', Syracuse, N. Y., 1981 , pp. $74-83$

J. K. Crellin, Br. J. Addict., 1980, 75, 153-162

87 J. Shoemaker, J. Am. Med. Assoc., 1893, 20,658

E. Wood, New York Med. I. 1893, 58, $435 \mathrm{ff}$.

88 J. P. Sheridan, New, York Med. J., 1899, 69, 634

89 W. H. Walling, Med. Surg. Rep., 1897, 76, 198

90 See Shoemaker $(87), 658$

91 See Shoemaker $(87), 656$

92 See Wood (87), 435

93 See Shoemaker (87), 656 and 658; Wood (87), 435; and (88), 634 H. C. Wood, J. Remington and S. Sadtler, 'Dispensatory of the United States of America', 15th Ed., Philadelphia, PA., 1883, pp. $271 \mathrm{ff}$. A. H. Ohmann-Dumesnil, New York Med. J., 1895, 61, 140-142

94 W. H. Walling, Med. Surg. Rep., 1895, 72, 122

95 R. Koch, Dtsche med. Wochenschr., 1890, 16, 756-757

96 R. Y. Keers, Thorax, 1980, 35, 884-889

97 M. J. Forestier, Bull. Mem. Soc, Med. Hop. Paris 1929, 323-327

98 Research Subcommittee of the Empire Rheumatism Council, Ann. Rheum. Dis., 1960, 19, 95-117

99 P. F. Hahn et al., J. Lab. Clin. Med., 1947, 32, 1442 'Radioactive Isotopes in Medicine and Biology: Medicine' . ed. S. Silver, Philadelphia, PA., 1962, p. 256

100 See Silver (99), p. 271

'Remington's Pharmaceutical Sciences', 16th Ed., ed. A. Osol et al., Easton, PA., 1980 , p. 458 